\title{
SELF-EMPLOYMENT AMONG CHINESE IMMIGRANTS IN NEW ZEALAND
}

\author{
Elsie Ho, Richard Bedford \\ and Joanne Goodwin \\ Migration Research Group, Department of \\ Geography, University of Waikato
}

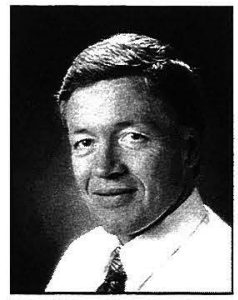

\begin{abstract}
This paper examines the self-employment patterns of Chinese immigrants in New Zealand, using labour force data provided in the 1996 Census of Population and Dwellings and survey data from interviews in New Zealand and Hong Kong. As expected, the census data show that the propensities to enter self-employment increase with age and length of residence in New Zealand. Amongst the Chinese immigrants who came to New Zealand after 1986, the pursuit of self-employment is unlikely to be confined to immigrants approved under the business immigration schemes. Structural barriers to employment, such as non-recognition of overseas qualifications and experiences, can also drive many contemporary Chinese immigrants into self-employment. The second part of the paper reflects on the business experiences of recent Chinese migrants in New Zealand, drawing on research carried out on the migration of entrepreneurs to New Zealand from Hong Kong during the 1990 's. We conclude our paper by discussing some of the implications of the Government's recent business immigration policy changes. We emphasize the need for a post-settlement policy and other initiatives that will ensure that immigrants are able to maximize their opportunities to contribute effectively to New Zealand's economy and society.
\end{abstract}

Keywords: Chinese immigrants, self-employment, labour force integration, business immigration policy

Until the 1970's, first-generation Chinese immigrants in New Zealand tended to engage in small-scale family businesses, particularly in retailing, restaurants and other personal services. Both societal forces and cultural factors had contributed to the development of ethnic businesses among the Chinese. Some scholars argued that the restrictive opportunities in the host society in the late nineteenth and early twentieth centuries had driven many early Chinese into peripheral businesses such as market gardening and laundry services (Fong, 1959; Lian, 1988). Discriminatory laws against the Chinese were repealed in the 1940's and 50 's, but other barriers such as the limited occupational skills of the Chinese immigrants and their lack of ability in the language of the host society, hindered their assimilation into New Zealand society. In the postwar decades, Chinese immigrants tended to concentrate in retailing, food and restaurant businesses which required very long hours of work, but slight knowledge of English and little capital (Young, 1973). The traditional values of industriousness, frugality and kinship ties also played a part in explaining the success of Chinese businesses (Ip, 1990, 1996).

Since the mid-1980's major changes in immigration regulations have substantially increased the entry of Chinese immigrants with professional, technical and entrepreneurial skills and much more investment capital than their predecessors (Ho and Farmer, 1994; Lidgard, Bedford and
Goodwin, 1998a, 1998b). A number of business immigration schemes, specifically designed to allow experienced business people to settle in New Zealand and develop new business opportunities, have been launched since 1986 (Burke, 1986; New Zealand Immigration Service, 1991; $1995 ; 1998)$. Until the early 1990's Hong Kong and Taiwan were the main two source countries of business migrants to New Zealand (Bedford, Ho, Lidgard and Goodwin, 1999). After major policy changes in October 1995 (New Zealand Immigration Service, 1995), especially the imposition of much stricter English language requirements for business migrants and their family members, applications decreased significantly (Ho and Bedford, 1998).

In an effort to regenerate some of the flows of business migrants into the country, a new policy of admitting business immigrants was announced in October 1998 (New Zealand Immigration Service, 1998). The unpopular NZ\$20,000 English language bond has been abolished and replaced with pre-purchased language training costing between NZ\$1,700 and NZ\$6,650. A new category has been introduced for entrepreneurs who have successfully established business in New Zealand. The policy also offers a simpler points system for entry for business investors, a new long-term, multiple re-entry visa for business people and more flexible residence arrangements for employees of businesses relocating to New Zealand. It is also planned 
that a Business Liaison Unit will be established to help business migrants identify investment opportunities and to settle in New Zealand (New Zealand Immigration Service, 1998).

Between April 1986 and March 1997, over 27,000 business immigrants and their dependents were approved for residence under the business immigration schemes, or 8.4 percent of all residence approvals to New Zealand during this period (Ho, Goodwin, Bedford and Spragg, 1997). Chinese business immigrants and their dependents from Hong Kong made up 38 percent of the business approvals, and those from Taiwan made up another 27 percent. The amount of investment capital accompanying these migrants was very impressive. Between July 1992 and June 1996, the investment funds accompanying approved business applications from Hong Kong were estimated to be $\$ 510$ million, and those from Taiwan were $\$ 209$ million (Ho and Bedford, 1998). Clearly, New Zealand's business immigration schemes have facilitated the entry of a large number of wealthy Chinese entrepreneurs from newly industrialised countries such as Hong Kong and Taiwan. These entrepreneurs are expected to contribute to the expansion of immigrant businesses and investment in this country.

Since 1991, a substantive number of Chinese immigrants also gained entry to New Zealand under the family reunification category, and a points system which rates prospective migrants on their qualifications, work experience, age and settlement factors (New Zealand Immigration Service, 1991; 1995; 1998). Between 1991 and 1997, over 50,000 people from Hong Kong, Taiwan and China had been granted permanent residence under the points system, and another 8,800 through family reunification (Ho, Goodwin, Bedford and Spragg, 1997). Unlike the Chinese who arrived in New Zealand at the turn of the century, the Chinese immigrants who have come under the points system are well educated and highly skilled professionals and managers with an urban, middle-class background (Henderson and Trlin, 1998; Ho and Farmer, 1994; Lidgard, 1996). Not surprisingly, their arrival in the 1990's has brought diversity to the once homogeneous Chinese community in New Zealand.

The rapid expansion of the Chinese immigrant population has drawn much interest recently especially with regard to employment opportunities for the new settlers. A preliminary examination of the 1996 census data, carried out by the migration research staff at the University of Waikato, has revealed that despite the high incidence of tertiary qualifications among Chinese recent immigrants (resident overseas in 1991) in the 20 to 49 age groups, unemployment rates ranged from 17 to 34 percent (Ho, Goodwin, Bedford and Spragg, 1997). These unemployment levels are well above the national average for these age groups. The data also show that among those immigrants who have managed to find work, many hold low-skilled or menial jobs in which they can make no use of their considerable experience and qualifications. The difficulties which many highly qualified new immigrants, as well as those who have been in the country for several years, have had in finding work in their fields of expertise have also been reported in a number of small-scale surveys (see, for example, Department of Internal Affairs, 1996; Friesen and Ip, 1997; Ho and Lidgard, 1997; Lidgard et al, 1998c).

There has been little research done in the area of self-employment among new immigrants. Despite the large number of Chinese immigrants approved under various business immigration schemes, studies have found that it has not been easy for them to establish a business here (Boyer, 1996; Lidgard, 1996). Lack of information about business investment opportunities and the domestic tax system, the small size of the New Zealand market and the monopoly of the producer boards were the main barriers to business (Lidgard, 1996). Recently, the New Zealand Immigration Service commissioned Forsyte Research to conduct a study with business migrants to investigate ways in which active business investment in New Zealand might be encouraged (Forsyte Research, 1998). The findings from this research were fed into the 1998 business immigration policy review.

It is unlikely that the pursuit of self-employment is confined to immigrants approved under the business immigration schemes. As noted earlier, structural barriers to employment such as an inability to speak the dominant language and discrimination by members of the host society, had forced many early Chinese immigrants to enter into self-employment. The barriers confronting many of our recent migrants include non-recognition of overseas qualifications and experiences. Such barriers can drive Chinese immigrants into self-employment as an alternative to wage labour.

While immigrants in general are more likely to be selfemployed than is the case with non-immigrants, the pursuit of self-employment is not necessarily uniform across all immigrant segments. As we have already shown, the Chinese immigrants who arrived in New Zealand after 1986 came with better qualifications, higher skills and much more capital compared with those who came two or more decades ago. The conditions of employment facing the two groups are therefore very different. Besides, the propensities to enter self-employment are also influenced by gender, age, length of residence in New Zealand and many other factors.

In this paper, we look at the self-employment patterns of Chinese immigrants and non-immigrants (the New Zealandborn Chinese) by gender, age and industry, using information provided in the 1996 Census of Population and Dwellings. The information from the census tabulations on the Chinese immigrant population is broken down by years of residence in New Zealand (less than five years; between five and ten years; over ten years) and selected birthplaces (China; Hong Kong; Taiwan; total overseas-born). The purpose of this systematic study is to find out the self-employment patterns of the Chinese immigrants who came to New Zealand after 1986, and compare them with those of the established Chinese immigrants and the non-immigrants. 
The second part of the paper draws on a survey conducted in 1998 in New Zealand and Hong Kong with Chinese migrants who have been involved in business activity in New Zealand during the 1990's. We look at the nature of the immigrant businesses established by the Chinese migrant entrepreneurs, their motives for starting a business and some of the factors that have contributed to, or hindered the development of recent Chinese businesses in New Zealand. The findings from this survey are used to complement and deepen our macro-level analysis of Chinese self-employment data provided in the 1996 census. We conclude our paper by discussing some of the implications of the Government's recent business immigration policy changes. We emphasize the need for a post-settlement policy and other initiatives which will ensure that immigrants are able to maximise their opportunities to contribute effectively to New Zealand's economy and society.

\section{Self employment levels in 1996}

The dataset for the first part of this investigation is labour force data on the Chinese descent population provided in the 1996 Census of Population and Dwellings. In 1996, there were 61,185 Chinese people aged 15 years and over resident in New Zealand; 11,199 were born in New Zealand and 49,986 were born overseas. We classify the overseas-born into three groups based on the information they provided in the Census regarding length of residence in New Zealand: the "recent immigrants" who had been resident in New Zealand for less than 5 years; the "newly established immigrants" with residence in NZ of between 5 and 10 years; and the "established immigrants" who had been resident in NZ for over 10 years. People who had not specified their length of residence in NZ in the Census were excluded from our study. The New Zealand-born Chinese are the "non-immigrants".

Table 1 shows the total number of Chinese "recent immigrants", "newly established immigrants", "established immigrants" and "non-immigrants" aged 15 years and over who were in the labour force and those who were not in the labour force in the 1996 Census. Large proportions of the Chinese recent immigrants and newly established immigrants were not in the labour force, particularly among the women (Table 1). Part of the explanation for the low labour force participation rates will relate to the difficulty these people have in getting into the labour force, as well as the family contexts within which individual migrants are situated. These issues have been discussed in other publications (see, for example, Ho, Bedford and Goodwin, 1997; Lidgard et al, 1998c) and will not be explored here.

Our investigation concerns the Chinese who were in the labour force in 1996. The labour force data in Table 2 clearly show that the employment patterns of the Chinese recent immigrants and newly established immigrants are very different from those of the established immigrants and the non-immigrants. Unemployment is a significant problem particularly for the recent immigrants. Besides, Chinese immigrants who were resident in New Zealand for less than 10 years (that is, the recent immigrants and the newly es- tablished immigrants) were more likely to become selfemployed than was the case of the non-immigrants, although not surprisingly the established immigrants of both sexes had the highest level of self-employment (Table 2). The recent immigrants and the newly established immigrants also had higher percentages in other employment such as unpaid family work (Table 2).

It is important to appreciate that within the "self-employed" are two groups: those people who work for themselves and have no employees, and those people who employ others (employers). The incidence of "self-employed with employees" was higher amongst the established immigrants and the non-immigrants (Table 2). Overall, males had higher proportions in self-employment than females.

Across the four groups of Chinese, the propensities to enter self-employment increase with age. Chinese people in the 40-59 age groups were more likely to become self-employed than was the case of those who were in the younger age groups (Table 3 ). The self-employment rates amongst the New Zealand-born Chinese (non-immigrants) in the older age groups are surprisingly high. In the previous table it is found that the overall self-employment rates were lower for the non-immigrants than the immigrants (Table 2 ). When self-employment is studied by age group, however, it is the New Zealand-born Chinese males in the 5059 age group that have the highest level of self-employment ( 52 percent). The New Zealand-born Chinese females in the 50-59 age group also had higher self-employment rates ( 26 percent) than the female recent immigrants in the same age group (10 percent).

At the 1996 Census established immigrants had the highest levels of self-employment in the 50-59 age group (50 percent for males and 35 percent for females). Immigrants who were resident in New Zealand for less than 10 years had the highest levels of self-employment in the 40-49 age group (Table 3). The exception is found in the newly established immigrant males who had the highest self-employment rate in the 50-59 age group. Table 3 also shows that recent immigrants in the 30-39 age group had the highest levels of unemployment. Over one in four of the Chinese immigrants resident in New Zealand for less than five years in the 30-39 age group were not working and were actively seeking employment.

The distribution of Chinese in major industry categories is summarised in Table 4. For this study, we grouped industries into four main categories: primary (agriculture, forestry, fishing and mining); secondary (manufacturing, building and construction); tertiary (utilities, trade and transport) and quaternary (financial, community, social and personal services). The percentages of Chinese employed in the four sectors are shown in Table 4. These percentages exclude people in the "industry not specified" category.

Across the four groups of self-employed Chinese, the recent immigrants and the newly established immigrants have very similar distributions. Both showed very low percentages in the primary industries, and high percentages in the 
Table 1. Total number of Chinese aged 15 years and over by gender and labour force participation in the 1996 Census

\begin{tabular}{|c|c|c|c|c|c|c|c|c|}
\hline \multirow[b]{3}{*}{ Labour force participation } & \multicolumn{4}{|c|}{ Overseas-born } & \multicolumn{4}{|c|}{ NZ-born } \\
\hline & \multicolumn{2}{|c|}{$\begin{array}{l}\text { *Recent } \\
\text { immigrants }\end{array}$} & \multicolumn{2}{|c|}{$\begin{array}{c}* * \text { Newly established } \\
\text { immigrants }\end{array}$} & \multicolumn{2}{|c|}{$\begin{array}{l}\text { ***Established } \\
\text { immigrants }\end{array}$} & \multicolumn{2}{|c|}{$\begin{array}{l}\text { Non- } \\
\text { immigrants }\end{array}$} \\
\hline & M & $\mathrm{F}$ & M & $\mathrm{F}$ & M & $\mathrm{F}$ & M & $\mathrm{F}$ \\
\hline In the labour force & 5151 & 4713 & 3378 & 3030 & 3111 & 2853 & 4563 & 3999 \\
\hline Not in labour force & 7650 & 10725 & 1602 & 2403 & 1110 & 1851 & 1083 & 1548 \\
\hline Total Number & 12801 & 15438 & 4980 & 5433 & 4221 & 4704 & 5646 & 5547 \\
\hline \multicolumn{9}{|c|}{$\begin{array}{l}\text { * Resident in NZ for less than } 5 \text { years } \\
\text { ** Resident in NZ for between } 5 \text { and } 10 \text { years } \\
\text { *** Resident in NZ for over } 10 \text { years }\end{array}$} \\
\hline $\begin{array}{l}\text { Source: Unpublished data fi } \\
\text { Population and Dwe }\end{array}$ & he Custo & omer Serv & ices Division & of Statistics & New Zeala & nd from & 96 Censu & \\
\hline
\end{tabular}

tertiary and quaternary sectors (Table 4 ). The recent immigrants had the highest percentages ( 16 percent of men and 11 percent of women) in the secondary industries, whereas the newly established immigrants were much more heavily represented ( 61 percent of males and 66 percent of females) in the tertiary sector than any other group of selfemployed Chinese in the 1996 Census.

In the case of the established immigrants and the non-immigrants, the percentages in the primary sector were higher, and those in the secondary industries were lower (Table 4). It is interesting to note that quaternary industries accounted for 19 to 22 percent of the Chinese established immigrants who were in self-employment. This pattern suggests that a sizeable proportion of the Chinese immigrants who had been resident in New Zealand for over 10 years has shifted away from the occupations of the earlier generations and had set up businesses in the financial, business and community sectors.
Across groups, Chinese women who were in self-employment in 1996 were more likely than men to be involved in the tertiary sector, and less likely in the secondary and quaternary sectors (Table 4). This observation regarding gender distribution in the tertiary and quaternary sectors, however, is the reverse of that found for Chinese who were not self-employed. Besides, self-employed Chinese had higher percentages in the tertiary sector, and lower percentages in the secondary and quaternary sectors than was the case for Chinese who were in other employment (Table 4).

In our discussion so far, we have examined the employment patterns of the Chinese immigrant population by gender, age, length of residence in New Zealand and industry, We have noted in particular, that the employment patterns of the Chinese who had been resident in New Zealand for less than 10 years were in many ways different from those who were in the country for over ten years. These differences can be partly explained by changes in New Zealand's

Table 2. Labour force status of Chinese aged 15 years and over, 1996

\begin{tabular}{|c|c|c|c|c|c|c|c|c|}
\hline \multirow[b]{3}{*}{ Labour force status } & \multicolumn{4}{|c|}{ Overseas-born } & \multicolumn{4}{|c|}{ NZ-born } \\
\hline & \multicolumn{2}{|c|}{$\begin{array}{l}\text { Recent } \\
\text { immigrants }\end{array}$} & \multicolumn{2}{|c|}{$\begin{array}{l}\text { Newly established } \\
\text { immigrants }\end{array}$} & \multicolumn{2}{|c|}{$\begin{array}{l}\text { Established } \\
\text { immigrants }\end{array}$} & \multicolumn{2}{|c|}{$\begin{array}{l}\text { Non- } \\
\text { immigrants }\end{array}$} \\
\hline & $\begin{array}{l}\mathrm{M} \\
\%\end{array}$ & $\begin{array}{r}\mathrm{F} \\
\%\end{array}$ & $\begin{array}{l}\mathrm{M} \\
\%\end{array}$ & $\underset{\%}{F}$ & $\begin{array}{l}\mathrm{M} \\
\%\end{array}$ & $\begin{array}{l}\mathrm{F} \\
\%\end{array}$ & $\begin{array}{l}\mathrm{M} \\
\%\end{array}$ & $\mathrm{~F}$ \\
\hline Self-employed (no employees) & 13.0 & 8.8 & 17.9 & 14.3 & 20.5 & 16.7 & 11.2 & 5.4 \\
\hline Self-employed (employees) & 5.1 & 3.1 & 9.8 & 6.5 & 16.4 & 9.7 & 10.6 & 4.8 \\
\hline Wage or salary eamers & 45.1 & 47.4 & 55.4 & 60.6 & 50.7 & 59.2 & 65.4 & 74.3 \\
\hline Other employment & 11.3 & 15.3 & 7.8 & 9.1 & 7.2 & 9.1 & 5.5 & 5.6 \\
\hline Seeking employment & 25.5 & 25.5 & 9.1 & 9.5 & 5.1 & 5.3 & 7.3 & 9.8 \\
\hline Total Number & 5151 & 4713 & 3378 & 3030 & 3111 & 2853 & 4563 & 3999 \\
\hline
\end{tabular}

Source: Unpublished data files prepared by the Customer Services Division of Statistics New Zealand from the 1996 Census of Population and Dwellings. 


\begin{tabular}{|c|c|c|c|c|c|c|c|c|}
\hline \multirow[b]{3}{*}{ Age group/Labour force status } & \multicolumn{4}{|c|}{ Overseas-born } & \multicolumn{4}{|c|}{ NZ-born } \\
\hline & \multicolumn{2}{|c|}{$\begin{array}{l}\text { Recent } \\
\text { immigrants }\end{array}$} & \multicolumn{2}{|c|}{$\begin{array}{l}\text { Newly established } \\
\text { immigrants }\end{array}$} & \multicolumn{2}{|c|}{$\begin{array}{l}\text { Established } \\
\text { immigrants }\end{array}$} & \multicolumn{2}{|c|}{$\begin{array}{l}\text { Non- } \\
\text { immigrants }\end{array}$} \\
\hline & $\begin{array}{l}\mathrm{M} \\
\%\end{array}$ & $\begin{array}{l}\mathrm{F} \\
\%\end{array}$ & $\begin{array}{l}\mathrm{M} \\
\%\end{array}$ & $\begin{array}{l}\mathrm{F} \\
\%\end{array}$ & $\begin{array}{l}\mathrm{M} \\
\%\end{array}$ & $\begin{array}{l}\mathrm{F} \\
\%\end{array}$ & $\begin{array}{l}\mathrm{M} \\
\%\end{array}$ & $\begin{array}{l}\mathrm{F} \\
\%\end{array}$ \\
\hline \multicolumn{9}{|l|}{$30-39$ years } \\
\hline Self-employed (no employees) & 10.6 & 10.7 & 17.1 & 15.3 & 19.4 & 19.1 & 13.8 & 8.3 \\
\hline Self-employed (employees) & 3.5 & 3.6 & 10.4 & 7.1 & 14.0 & 8.8 & 15.5 & 6.1 \\
\hline Wage or salary earners & 51.1 & 50.0 & 61.0 & 63.9 & 56.2 & 57.4 & 62.1 & 74.2 \\
\hline Other employment & 6.2 & 9.2 & 5.2 & 7.4 & 5.8 & 9.6 & 4.0 & 5.5 \\
\hline Seeking employment & 28.6 & 26.4 & 6.3 & 6.4 & 4.7 & 5.2 & 4.5 & 5.8 \\
\hline \multicolumn{9}{|l|}{$40-49$ years } \\
\hline Self-employed (no employees) & 24.0 & 14.4 & 23.8 & 19.2 & 22.1 & 17.3 & 19.1 & 6.4 \\
\hline Self-employed (employees) & 9.0 & 5.1 & 12.2 & 7.9 & 19.5 & 12.3 & 20.5 & 12.3 \\
\hline Wage or salary earners & 36.8 & 46.4 & 47.3 & 56.0 & 47.9 & 59.4 & 52.7 & 70.6 \\
\hline Other employment & 11.2 & 15.5 & 8.9 & 10.2 & 6.6 & 6.9 & 4.1 & 4.8 \\
\hline Seeking employment & 19.0 & 18.7 & 7.7 & 6.8 & 4.0 & 4.1 & 3.6 & 5.9 \\
\hline \multicolumn{9}{|l|}{$50-59$ years } \\
\hline Self-employed (no employees) & 22.4 & 5.8 & 26.7 & 18.9 & 26.8 & 22.8 & 29.7 & 13.7 \\
\hline Self-employed (employees) & 9.7 & 4.3 & 12.8 & 9.4 & 23.5 & 12.3 & 22.5 & 12.8 \\
\hline Wage or salary earners & 29.1 & 26.1 & 40.7 & 49.1 & 41.0 & 52.5 & 43.5 & 64.1 \\
\hline Other employment & 17.2 & 34.8 & 11.6 & 11.3 & 4.4 & 8.6 & 2.9 & 5.1 \\
\hline Seeking employment & 21.6 & 29.0 & 8.1 & 11.3 & 4.4 & 3.7 & 1.4 & 4.3 \\
\hline
\end{tabular}

Source: Unpublished data files prepared by the Customer Services Division of Statistics New Zealand from the 1996 Census of Population and Dwellings.

Table 4. Employment of Chinese in major industries, 1996

\begin{tabular}{|c|c|c|c|c|c|c|c|c|}
\hline \multirow{4}{*}{ Employment/Industry } & \multicolumn{4}{|c|}{ Overseas-born } & \multicolumn{4}{|c|}{ NZ-born } \\
\hline & \multicolumn{2}{|c|}{$\begin{array}{l}\text { Recent } \\
\text { immigrants }\end{array}$} & \multicolumn{2}{|c|}{$\begin{array}{l}\text { Newly established } \\
\text { immigrants }\end{array}$} & \multicolumn{2}{|c|}{$\begin{array}{l}\text { Established } \\
\text { immigrants }\end{array}$} & \multicolumn{2}{|c|}{$\begin{array}{l}\text { Non- } \\
\text { immigrants }\end{array}$} \\
\hline & $\mathrm{M}$ & $\mathrm{F}$ & $\mathrm{M}$ & $\mathrm{F}$ & $\mathrm{M}$ & $\mathrm{F}$ & $\mathrm{M}$ & $\mathrm{F}$ \\
\hline & $\%$ & $\%$ & $\%$ & $\%$ & $\%$ & $\%$ & $\%$ & $\%$ \\
\hline \multicolumn{9}{|l|}{ Self-employment } \\
\hline Primary & 3.6 & 4.1 & 4.8 & 4.1 & 11.1 & 14.5 & 18.7 & 10.1 \\
\hline Secondary & 15.7 & 11.2 & 13.0 & 10.8 & 9.2 & 7.3 & 12.7 & 7.0 \\
\hline Tertiary & 49.6 & 57.4 & 61.3 & 66.0 & 58.1 & 59.0 & 34.8 & 48.8 \\
\hline Quatemary & 31.1 & 27.2 & 20.9 & 19.1 & 21.7 & 19.2 & 33.9 & 34.1 \\
\hline \multicolumn{9}{|l|}{ Other employment } \\
\hline Primary & 3.1 & 3.0 & 3.0 & 1.8 & 3.2 & 4.1 & 6.3 & 3.1 \\
\hline Secondary & 23.8 & 26.3 & 24.2 & 21.1 & 28.8 & 17.5 & 23.4 & 8.9 \\
\hline Tertiary & 43.4 & 38.2 & 46.7 & 35.5 & 34.7 & 31.7 & 35.8 & 36.7 \\
\hline Quaternary & 29.7 & 32.5 & 26.1 & 41.7 & 33.3 & 46.7 & 34.5 & 51.3 \\
\hline $\begin{array}{l}\text { Source: Unpublished d } \\
\text { Population and }\end{array}$ & ed by $t$ & Custo & ces $\mathrm{Di}$ & sion of Statist & New Z & aland $\mathrm{f}$ & $996 \mathrm{Ce}$ & \\
\hline
\end{tabular}


Table 5. Labour force status of Chinese immigrants resident in New Zealand for less than 10 years by selected birthplaces, 1996

\begin{tabular}{lrrrrrrrrr}
\hline & \multicolumn{2}{c}{ China Born } & \multicolumn{3}{c}{ Hong Kong Born } & \multicolumn{2}{c}{ Taiwan Born } & \multicolumn{2}{c}{ Total; overseas-born } \\
& M & F & M & F & M & F & M & F \\
Years in NZ/Labour force status & $\%$ & $\%$ & $\%$ & $\%$ & & $\%$ & $\%$ & $\%$ & $\%$ \\
\hline Less than 5 years ("recent" immigrants) & & & & & & & & & \\
Self-employed (no employees) & 9.9 & 8.0 & 20.1 & 14.2 & 17.9 & 12.1 & 13.0 & 8.8 \\
Self-employed (employees) & 3.2 & 2.3 & 8.0 & 5.3 & 8.5 & 4.5 & 5.1 & 3.1 \\
Wage or salary earners & 48.8 & 48.4 & 41.8 & 47.8 & 28.2 & 29.3 & 45.1 & 47.4 \\
Other employment & 8.8 & 12.4 & 12.4 & 16.2 & 18.8 & 27.3 & 11.3 & 15.3 \\
Seeking employment & 29.4 & 28.8 & 17.7 & 16.6 & 26.5 & 26.8 & 25.5 & 25.5 \\
& & & & & & & & \\
Between 5 and 10 years ("newly established" immigrants) & & & & & & \\
Self-employed (no employees) & 21.5 & 21.5 & 17.0 & 12.3 & 21.5 & 13.0 & 17.9 & 14.3 \\
Self-employed (employees) & 10.9 & 8.8 & 12.5 & 8.5 & 17.2 & 10.0 & 9.8 & 6.5 \\
Wage or salary earners & 50.0 & 48.8 & 52.7 & 61.3 & 25.8 & 41.0 & 55.4 & 60.6 \\
Other employment & 9.2 & 12.5 & 8.0 & 7.5 & 18.3 & 16.0 & 7.8 & 9.1 \\
Seeking employment & 8.5 & 8.4 & 9.8 & 10.4 & 17.2 & 20.0 & 9.1 & 9.5 \\
\hline
\end{tabular}

Source: Unpublished data files prepared by the Customer Services Division of Statistics New Zealand from the 1996 Census of Population and Dwellings.

immigration regulations since 1986, which removed racial origin as a consideration in immigration and emphasised professional, technical and entrepreneurial skills of immigrants (Burke, 1986; New Zealand Immigration Service, 1991; 1995; 1998).

It is important to appreciate that the Chinese who arrived in New Zealand after the 1986 policy changes were from a variety of countries of origin (Bedford and Lidgard, 1996; Lidgard, Bedford and Goodwin, 1998b). Between 1986 and 1996, there was a net migration gain to New Zealand of 73,880 people (Lidgard, Bedford and Goodwin, 1998b, p.15). Just over two-thirds of this gain came from three sources: the People's Republic of China $(16,430)$, Hong Kong $(17,570)$ and Taiwan $(16,260)$ (Lidgard, Bedford and Goodwin, 1998a, p.39 and p.41). The three Chinese groups are quite different from one another, in terms of demographic profiles as well as motives for migration, categories under which their entry to New Zealand was approved, occupation prior to immigration, English ability, etc. (Friesen and Ip, 1997; Lidgard et al, 1998c). Differences in their employment patterns at the 1996 Census are considered below.

Table 5 gives the labour force data for people of Chinese ethnic descent whose birthplaces are China, Hong Kong and Taiwan and whose length of residence in New Zealand is either less than 5 years or between 5 and 10 years. Data on the overseas-born Chinese are also provided for comparison purposes. It must be remembered that some immigrants from Hong Kong and Taiwan would have been born in China and hence the employment data for the three birthplace groups shown in Table 5 cannot claim to provide precise profiles of those Chinese immigrants coming from the three sources. Nonetheless, the data clearly show that there are great variations in the employment patterns within the Chinese immigrant population who came to New Zealand after the 1986 policy changes.

In the case of the Chinese immigrants who have resided in New Zealand for less than five years (the "recent immigrants"), those who were born in Hong Kong and Taiwan were much more likely to be in self-employment than was the case for the China-born (Table 5). This difference can probably be explained by the migration categories under which they enter. In the late 1980's and early 1990's immigrants from Hong Kong and Taiwan were the main two sources of business migrants to New Zealand (Bedford, Ho, Lidgard and Goodwin, 1999). These migrants with a business track record and considerable investment funds were more likely to become self-employed when they came to live in New Zealand. On the other hand, most migrants from the People's Republic of China had entered under the points system on the basis of their qualifications and skills. Hence they were more likely to be looking for wage or salary employment in this country. Indeed, amongst the Chinese recent immigrants at the 1996 Census, the Chinaborn group had the highest percentages of wage or salary earners (Table 5). This group also had the highest percentages of unemployment (Table 5).

The employment patterns of the Chinese immigrants who had been resident in New Zealand for between five and ten years (the "newly established immigrants") are different. Across the three birthplace groups, the China-born had the lowest levels of unemployment and high percentages of self-employment with no employees (Table 5). These patterns clearly differ from those of the China-born recent immigrants, who had very high levels of unemployment and very low incidence of self-employment in 1996 (see 
Table 5). We have explained earlier that recent immigrants from China are more likely to be looking for paid employment rather than self-employment in New Zealand because most have gained entry on the basis of their qualifications and skills. However, the census data also suggest that large proportions of the China-born have entered into self-employment after residence in New Zealand for five years or more. This reflects in part the problem of finding employment in New Zealand. Apparently, self-employment has become a significant alternative for many contemporary China-born migrants who are unable to find employment that can fully utilise their skills and abilities.

There are some similarities between the employment patterns of the China-born and the Taiwan-born Chinese immigrants. Both groups show a growing incidence of selfemployment and declining unemployment with longer residence in New Zealand (Table 5). Apparently the disappointment with finding employment has also driven many Taiwan-born into self-employment. It must also be remembered that many migrants from Taiwan were business people prior to migration and hence are more likely to have set up their own businesses after they become settled in New Zealand. Table 5 shows that the highest percentages of employers (self-employed with employees) are found amongst the newly established Chinese immigrants born in Taiwan.

Although many more immigrants from Hong Kong had gained entry to New Zealand under the business immigration schemes, the Hong Kong-born Chinese immigrants do not have much higher self-employment rates than those immigrants whose birthplaces are China and Taiwan (Table 5 ). This reflects, in part, that some business migrants have not established a business in New Zealand. This also suggests that the pursuit of self-employment is not necessarily confined to immigrants approved under the business immigration schemes. We have argued earlier that structural barriers to employment, such as non-recognition of overseas qualifications and experiences, can drive some contemporary Chinese immigrants into self-employment.

Clearly, the business experiences of contemporary Chinese migrants in New Zealand have been quite mixed. The next section reflects on some of these experiences, drawing on micro-level research into the migration of entrepreneurs to New Zealand from Hong Kong during the 1990's.

\section{Business experiences of Chinese migrants}

In this section we trace the experiences of some Hong Kong migrants who have been involved in business activity in New Zealand during the 1990's, using material derived from 42 in-depth interviews. These interviews were conducted in New Zealand and Hong Kong between March and June 1998 (Ho, Bedford, Wong and Tang, 1999). Twenty-three of the respondents who were interviewed have businesses in New Zealand. The remainder were not doing business in this country at the time of the survey (Table 6).

Contrary to the popular belief that Chinese business mi- grants in New Zealand are middle-aged men who are very wealthy, our study found that they are a heterogeneous group by age, educational qualification, settlement plans, business experiences and motives for doing business in New Zealand (Table 6). Although a majority had gained entry under the business immigration schemes, some entered under other categories (Table 6).

Over half of respondents who have a business in New Zealand had no direct business experiences before migration (Table 6). Three of them are young migrants in their 20's. They came to New Zealand in the late 1980's with their parents and had their education here. With active encouragement and some financial support from their parents, all three were able to set up a business in their field of interest shortly after they finished education. As their parents are themselves business migrants in New Zealand, they can count on their parents for advice when they have a problem in their business.

The remaining ten Hong Kong entrepreneurs who had no business experiences prior to migration are in the older age groups. All except two are very experienced in the type of industry where they eventually established a business. A majority gained their relevant work experiences prior to migration, and six had also worked in local companies before starting their own business.

Only two respondents who have a business in New Zealand had neither a business track record nor direct work experiences in their business area. One of them is a former computer programmer who came in the late 1980's under the Business Immigration Policy. His original business plan was to run a motel. After he arrived in New Zealand, he underwent retraining to become a real estate agent, a job which gave him the opportunity to get in touch with people who want to buy or sell properties or businesses. He visited a large number of motel sites in the North Island but finally decided to run a grocery shop instead because his family did not want to move out of Auckland.

The other respondent runs a small business in fruit marketing. A former secondary school teacher from Hong Kong, this respondent gave up his high-pay job to come to New Zealand in the mid-1990's under the points system. Originally his plan was to retire. But after living in the country for a year, he felt bored and wanted to do something to occupy his time. At the time of the survey, the respondent had run the business for nine months. He was not sure if he would continue with this business as it took up a lot of his time and the return was only small.

Setting up a business appears to be less of a challenge for those entrepreneurs who had some business experience prior to migration. Nine of the ten respondents who were in this category set up a business within three years after they settled in New Zealand. However the size of the business they now have is much smaller than the one they had previously. The majority have no employees or employ less than five persons (Table 7) and hence have had to spend more time in their business than previousiy. 


\begin{tabular}{|c|c|c|c|c|}
\hline & \multicolumn{2}{|c|}{ Business in NZ } & \multicolumn{2}{|c|}{ No business in $\mathrm{N}_{2}$} \\
\hline & $\mathrm{N}$ & $\%$ & $\mathrm{~N}$ & $\%$ \\
\hline \multicolumn{5}{|l|}{ Gender } \\
\hline Male & 21 & 91 & 15 & 79 \\
\hline Female & 2 & 9 & 4 & 21 \\
\hline Total & 23 & 100 & 19 & 100 \\
\hline \multicolumn{5}{|l|}{ Age } \\
\hline $20-39$ years & 7 & 30 & 1 & 5 \\
\hline $40-59$ years & 14 & 61 & 17 & 89 \\
\hline $60+$ years & 2 & 9 & 1 & \\
\hline \multicolumn{5}{|l|}{ Highest education level } \\
\hline Diploma and above & 14 & 61 & 5 & 26 \\
\hline Secondary schooling & 7 & 30 & 12 & 63 \\
\hline Primary schooling & 2 & 9 & 2 & 11 \\
\hline \multicolumn{5}{|l|}{ Permanent residence category } \\
\hline Business & 17 & 74 & 17 & 89 \\
\hline Other & 6 & 26 & 2 & 10 \\
\hline \multicolumn{5}{|l|}{ Family living arrangements } \\
\hline Whole family in NZ & 15 & 65 & 5 & 26 \\
\hline Whole family in $\mathrm{HK}$ & 0 & 0 & 3 & 16 \\
\hline Some members living overseas & 8 & 35 & 11 & 58 \\
\hline \multicolumn{5}{|l|}{ Years of business experience in $\mathrm{HK}$} \\
\hline No direct experience & 13 & 57 & 3 & 16 \\
\hline Under 10 years & 2 & 9 & 7 & 37 \\
\hline Over 10 years & 8 & 35 & 9 & 47 \\
\hline \multicolumn{5}{|c|}{ Motives for starting a business in NZ } \\
\hline To be one's own boss & 8 & 35 & 3 & 16 \\
\hline Earn a living & 7 & 30 & 1 & 5 \\
\hline By chance & 4 & 17 & 0 & 0 \\
\hline Occupy time & 3 & 13 & 0 & 0 \\
\hline Business investment & 1 & 4 & 2 & 11 \\
\hline Not applicable & 0 & 0 & 13 & 68 \\
\hline
\end{tabular}

Source: Ho, Bedford, Wong and Tang, 1999

"To be one's boss" was the main motive for starting a business in New Zealand given by just over one-third of the Hong Kong entrepreneurs (Table 6). Among them are highly-skilled professionals; some also had New Zealand qualifications and local work experiences. Many of the respondents in this category believed that there are structural barriers to employment and hence entering self-employment is a desirable alternative. "To earn a living" or "to occupy time" were the motives for doing business for many older migrants. Four respondents entered into self-employment "by chance". These included two in the manufacturing industry who bought their business from their boss who went on retirement. One businessman runs a business in professional services in Hong Kong and a motel business in New Zealand; he considered his business in New Zealand as an investment.
The rapid increase in the Chinese immigrant population in the early 1990's has created an enlarged Chinese consumer market and thus new opportunities for doing ethnic businesses for Chinese immigrants. About half of the immigrant businesses established by the Hong Kong entrepreneurs cater primarily for Chinese customers (Table 7). Not surprisingly, large proportions of these businesses are in the real estate, restaurant, retailing and trade sectors (Table 7).

Out of the 42 respondents who participated in this study, 19 were not engaged in business in New Zealand when they were interviewed (Table 6). All except two entered under the business immigration schemes. The other two who gained entry under other categories had had a business in New Zealand previously. Overall, the respondents in this group are older in age and are less qualified than is 
the case of those who are currently doing business in New Zealand (Table 6).

The business experiences of these 19 respondents were very mixed. Ten of them were in Hong Kong at the time of the survey and most had a business there. Among them two had lost a considerable amount of money in a business investment in New Zealand. Of the nine who lived in New Zealand, four had run businesses that ended in failure. The remaining five had spent a considerable amount of time exploring business ventures in New Zealand but had not found any likely to be viable. Three finally decided to find work and managed to return to wage employment. One of the two who had no work nor business had returned to Hong Kong to continue with his business there. The other one is considering moving back to Hong Kong when his family has obtained New Zealand passports.

The mixed experiences of this group can also be reflected in their family living arrangements (Table 6). We mentioned earlier that ten respondents in this group lived in Hong Kong. Among them, only three lived with the entire family. Of the nine who lived in New Zealand, only five lived with the entire family. The rest had some members in both countries. This 'astronaut' phenomenon has drawn considerable attention from the media and the public since the early 1990's (Boyer, 1996; Ho, Bedford and Goodwin,

\section{Table 7. Main characteristics of businesses established by Hong Kong entrepreneurs}

\begin{tabular}{lrr}
\hline & Number & Percent \\
\hline Business type & & \\
$\quad$ Sole proprietorship & 13 & 57 \\
Partnership & 6 & 26 \\
Family business & 4 & 17 \\
Total & 23 & 100 \\
Number of employees & & \\
No employees & 7 & 30 \\
Under 5 & 14 & 61 \\
5 to 10 & 1 & 4 \\
Over 10 & 1 & 4 \\
Ethnicities of customers & & \\
$\quad$ Mainly Chinese & & \\
Mainly Europeans & 10 & 43 \\
Mainly Maori/Pacific Islanders & 7 & 30 \\
Mixed & 1 & 4 \\
Industry type & 5 & 22 \\
$\quad$ Agriculture, forestry and fishing & 2 & \\
Manufacturing & 3 & 13 \\
Wholesale and retail trade & 6 & 26 \\
Accommodation, cafes and restaurants & 4 & 17 \\
Property and business services & 6 & 26 \\
Cultural and recreational services & 2 & 9 \\
\end{tabular}

Source: Ho, Bedford, Wong and Tang, 1999
1997; Lidgard, 1996; Lidgard et al, 1998c). In comparison, Hong Kong families who have a business in New Zealand are less likely to adopt the 'astronaut' strategy (Table 6).

\section{Migrant settlement issues}

Our interviews highlighted a number of difficulties Chinese migrant entrepreneurs face in trying to set up a business in New Zealand. Lack of local connections, and ignorance of government regulations and local market forces were seen to be the main disadvantages (Ho, Bedford, Wong and Tang, 1999). Even some experienced business migrants admit that they had underestimated the problems they would have to face in establishing their business in a new and unfamiliar business milieu. Migrants who have little or no business experience have to face the added challenge of learning to do business, and to live with unstable income, labour problems and long working hours.

Hong Kong migrant entrepreneurs are also critical of New Zealand's business immigration policy, especially the English language requirements and the ambiguity about the criteria by which returning residents' visas are issued. In the October 1998 immigration policy announcements, the stringent English language requirements for business $\mathrm{mi}$ grants were removed (New Zealand Immigration Service, 1998). Policy regarding the returning resident's visa is currently under review. Clearly, the Government is keen to continue promoting business immigration in the hope of attracting innovative entrepreneurs with investment capital to New Zealand (Bedford and Ho, 1998). However, from the responses given by Hong Kong migrant businessmen in New Zealand and in Hong Kong, it is also clear that unless the Government does more to assist new migrants come to grips with the local entrepreneurial environment then their business immigration policy will remain relatively unsuccessful.

We have argued elsewhere that the recent immigration policy changes have not attempted to address the issue of post-arrival settlement in New Zealand (Bedford and Ho, 1998; Ho and Bedford, 1998). The proposal to establish a Business Liaison Unit is a positive initiative, but it has a narrow focus aiming at helping business migrants "identify investment opportunities, connect with mentors and easily access information about the way business is done in New Zealand" (New Zealand Immigration Service, 1998, p.10). No doubt business migration is an important component of the Government's immigration policy, but as our research has found, the employment and settlement experiences of Chinese migrants are very mixed. Migrants who enter under the business migration category often end up doing other work while migrants who come under other categories clearly can move into self-employment. If the business immigration programme is to produce the outcomes expected by government, then there must be a comprehensive migrant settlement programme which will ensure that immigrants are able to maximise their opportunities to contribute effectively to New Zealand's economy and society. 


\section{Future research}

Recent studies on the employment experiences of Asian migrants tend to focus on the unemployment and underemployment problems they face. There has been little research done in the area of self-employment amongst these immigrants. It is possible that this lack of interest is due to a misconception that self-employed migrants tend to be wealthy and may not be affected by the problems encountered by other migrants. However, our study has revealed that the Chinese self-employed population is a heterogeneous group by age, gender, countries of origin, etc. A topic for future research is the experiences of migrants from the People's Republic of China, as this group seems to enter into self-employment for different reasons from those who enter from Hong Kong and Taiwan. Another topic concerns the New Zealand-born Chinese, who have very high selfemployment rates in the older age groups. It would be useful to explore whether their entry into self-employment is a result of continued discrimination in the labour market, or is due to other factors.

Recent studies in Canada and Australia have found that capital-intensive Chinese corporate enterprises have gradually replaced small-scale and family-oriented business in the two countries (Ip, Wu and Inglis, 1998; Li, 1993). There is yet little evidence for the development of corporate enterprises by Chinese entrepreneurial migrants in New Zealand. A comparative study on the development of Chinese businesses in these three countries would be useful, as it would contribute to our understanding of the relationships between migration and ethnic entrepreneurship.

\section{Acknowledgements}

The authors wish to acknowledge assistance received from the Foundation for Research, Science and Technology and the Asia 2000 Foundation of New Zealand for financial support; the Client Services Section of Statistics New Zealand in Christchurch for providing the 1996 census data used in this study; members of the Chinese communities in New Zealand and Hong Kong who participated in the interviews; and the Centre of Asian Studies at the University of Hong Kong, and the Department of Geography and the Population Studies Centre at the University of Waikato for logistical support with this research.

\section{References}

Bedford, R. and Ho, E. (1998) Immigration policy changes in 1998: a comment. New Zealand Population Review, 24, 119-134

Bedford, R. and Lidgard, J. (1996) International migration in the Asia-Pacific region, 1986-1996: a New Zealand perspective. Population Studies Centre Discussion Paper No.19. Hamilton: University of Waikato.

Bedford, R., Ho, E., Lidgard, J. and Goodwin, J. (1999) Business migration schemes in New Zealand: review and prospect. Migrant Entrepreneurship and the Development of New Zealand's Links with
Hong Kong. Proceedings of a Workshop Organised by the Migration Research Group, 25 July 1998. Hamilton: University of Waikato (forthcoming).

Boyer, T. (1996) Problems in paradise: Taiwanese immigrants to Auckland, New Zealand Asia Pacific Viewpoint 37(1): 59-79.

Burke, K. (1986) Review of Immigration Policy August 1986: Appendix G.42 to Journal of the House of Representatives Wellington: Government Printer.

Department of Internal Affairs (1996) High Hopes: A Survey of Qualifications, Training and Employment Issues for Recent Immigrants in New Zealand Wellington: Department of Internal Affairs.

Fong, N.B. (1959) The Chinese in New Zealand: a study in assimilation Hong Kong: Hong Kong University Press.

Forsyte Research (1998) Experiences of recent business migrants in New Zealand. Unpublished Market Research Report prepared for the New Zealand Immigration Service, September.

Friesen, W. and Ip, M. (1997) New Chinese New Zealanders: profile of a transnational community in Auckland. In East Asian New Zealanders: Research on New Migrants. Asia-Pacific Migration Research Network (New Zealand) Research $\mathrm{Pa}$ pers. Albany: Department of Sociology, Massey University, 3-19.

Henderson, A. and Trlin, A. (1998) New Chinese - changing characteristics: a New Settlers Programme profile Paper presented at the Seminar on Chinese in Australasia and the Pacific: Old and New Migrations and Cultural Change, University of Otago and Association for the Study of the Chinese and their Descendants in Australasia and the Pacific, 20-22 November.

Ho, E.S. and Bedford, R.D. (1998) The Asian crisis and migrant entrepreneurs in New Zealand: some reactions and reflections New Zealand Population Review, 24, 71-101.

Ho, E.S. and Farmer, R. (1994) The Hong Kong Chinese in Auckland in R. Skeldon (ed.) Reluctant exiles? Migration from Hong Kong and the new overseas Chinese New York: M.E. Sharpe, 215-232.

Ho, E.S. and Lidgard, J.M. (1997) Give us a chance: the employment experiences of new setters from East Asia. In P. Morrison (ed.) Labour, Employment and Work in New Zealand 1996. Proceedings of the Seventh Conference, November $28 \& 29$, 1996. Wellington: Victoria University of Wellington, 126-132.

Ho, E.S., Bedford, R.D. and Goodwin, J. (1997) “Astronaut" families: a contemporary migration phenomenon. In East Asian New Zealanders: Research on New Migrants. Asia-Pacific Migration Research Network (New Zealand) Research $\mathrm{Pa}$ - 
pers. Albany: Department of Sociology, Massey University, 3-19.

Ho, E.S., Goodwin, J.E., Bedford, R.D. and Spragg, B. (1997) Migrants in the workforce: a preliminary comparison of the experiences of Chinese and Korean recent immigrants in 1991 and 1996 Briefing Paper prepared for the participants at the Population Conference, Wellington 12-14 November 1997 Hamilton: University of Waikato.

Ho, E.S., Bedford, R.D., Wong, S.L. and Tang, M. (1999) Entrepreneurial activities of Hong Kong migrants in New Zealand and Hong Kong. In Migrant Entrepreneurship and the Development of New Zealand's Links with Hong Kong. Proceedings of a Workshop Organised by the Migration Research Group, 25 July 1998. Hamilton: University of Waikato (forthcoming).

Ip, D., Wu, C-T. and Inglis, C. (1998) Settlement experiences of Taiwanese immigrants in Australia Asia Studies Review 22(1) 79-97.

Ip, M. (1990) Home away from home: life stories of Chinese women in New Zealand Auckland: New Women's Press.

Ip, M. (1996) Dragons on the Long White Cloud North Shore City: Tandem Press.

Li, P.S. (1993) Chinese investment and business in Canada: ethnic entrepreneurship reconsidered Pacific Affairs 66(2) 219-243.

Lian, K.F. (1988) The sociopolitical process of identity formation in an ethnic community: the Chinese in New Zealand Ethnic and Racial Studies, 11(4): 506-532.

Lidgard, J.M. (1996) East Asian migration to Aotearoa' New Zealand: perspectives of some new arrivals Population Studies Centre Discussion Paper No 12 Hamilton: University of Waikato.

Lidgard, J.M., Bedford, R.D. and Goodwin, J.E. (1998a) Transformation in New Zealand's international migration system: 1981-1996, Population Studies Centre Discussion Paper No. 25. Hamilton: University of Waikato.

Lidgard, J.M., Bedford, R.D. and Goodwin, J.E. (1998b) International migration from Northeast Asia and population change in New Zealand, 1986-1996, Population Studies Centre Discussion Paper No. 26. Hamilton: University of Waikato.

Lidgard, J.M., Ho. E.S., Chen, Y.Y., Goodwin, J.E. and Bedford, R.D. (1998c) Immigrants from Korea, Taiwan and Hong Kong in New Zealand in the mid-1990's: micro and macro perspectives, Population Studies Centre Discussion Paper No. 29. Hamilton: University of Waikato.

New Zealand Immigration Service (1991) New Zealand's Immigration Policy Wellington.

New Zealand Immigration Service (1995) New Zealand's targeted immigration policies: summary of October 1995 policy changes Wellington.

New Zealand Immigration Service (1998) Destination New Zealand: summary of October 1998 policy changes Wellington.

Young, M.L. (1973) The Auckland Chinese: a community in transition M.A. thesis in Geography, University of Auckland.

\section{Authors}

Elsie Ho is a Research Fellow in the Department of Geography, Richard Bedford is Professor of Geography and Joanne Goodwin is a Researcher (in the same department). University of Waikato,

Private Bag 3105, Hamilton.

E-mail: elsieho@waikato.ac.nz 